Meta

Journal des traducteurs

Translators' Journal

\title{
Marked and Unmarked Translation: An Approach from Semiotically Based Natural Text Linguistics
}

\section{Wolfgang U. Dressler}

Volume 35, numéro 1, mars 1990

Actes du colloque international « La traduction proligère "

URI : https://id.erudit.org/iderudit/002588ar

DOI : https://doi.org/10.7202/002588ar

Aller au sommaire du numéro

Éditeur(s)

Les Presses de l'Université de Montréal

ISSN

0026-0452 (imprimé)

1492-1421 (numérique)

Découvrir la revue

Citer cet article

Dressler, W. U. (1990). Marked and Unmarked Translation: An Approach from Semiotically Based Natural Text Linguistics. Meta, 35(1), 138-148.

https://doi.org/10.7202/002588ar d'utilisation que vous pouvez consulter en ligne. 


\section{MARKED AND UNMARKED TRANSLATION: AN APPROACH FROM SEMIOTICALLY BASED NATURAL TEXT LINGUISTICS}

WoLFGANG U. DRESSLER

Universität Wien, Vienna, Austria

\section{INTRODUCTION}

In this contribution I am trying to show how a semiotically based natural text linguistic model can be applied to the study of translation. This model (Dressler 1989; Merlini 1988; Dressler and Merlini 1987) derives from two sources: 1) a procedural model of text linguistics (see Beaugrande and Dressler 1981; for text production, see Beaugrande 1984, for translation, Beaugrande 1979 and Dressler 1987) which also fits well to contemporary processual models of translation (Königs 1986: 127f); 2) the markedness/preference approach of natural phonology and natural morphology based on a semiotic metatheory as in Dressler (1985). In this framework "marked" stands for "more marked than" or "dispreferred" or "less natural than" and, correspondingly, "unmarked" for "less marked than" or "preferred" or "more natural than". Applied to the text level this means that in text production often more vs. less marked options are available. Now, if a translator translates either an unmarked option from the source text into an equally unmarked option of the target text or a marked option into an equally marked option, then this represents an unmarked translation. If he/she translates an unmarked option into a marked option or vice versa, then this represents a marked translation, and if there is no justification for this markedness switch, then this is an inadequate translation. Here I must restrict my discussion to textual microstructures.

My markedness approach is based on Peircean semiotics (Peirce 1965; Buchler 1955; Hookway 1985; Eco 1984) because, first of all, if linguistics deals with language as a system of verbal signs, and if semiotics deals with signs in general, then semiotics is an appropriate metatheory for linguistic theory; second, Peircean semiotics seems to be a semiotic model particularly adequate for use in linguistics (Dressler 1989).

Moreover, Peircean semiotics seems also to be quite adequate for modelling translation as a specific type of semiosis where characteristic iconic and indexical relations must obtain. But let me just briefly discuss the thorny problem of translation equivalence (Reiss and Vermeer 1984) which can be modeled as an equivalence of the Peircean interpretant. This interpretant is the communicative (or cognitive) effect of using a sign in semiosis, or in Peircean words: (a produced or received sign) "addresses somebody, that is, it creates in the mind of that person an equivalent sign or perhaps a more developed sign. That which it creates, I call the interpretant of the first sign." In translation, the person addressed may be both the producer of the original text, the translator, or the recipient of the translator. Let us focus on the intended recipient of both the original text and of the translation. Now the interpretant (i.e., the sign created in the minds) of both recipients must be equivalent.

However, Peirce distinguishes between several types of interpretants, of which I can discuss here only the first and the last. The first one, which corresponds to what we 
normally call "sense", is the "immediate interpretant"; in Peirce's words: "My immediate interpretant is implied in the fact that each sign must have its peculiar interpretability before it gets any interpreter." This may be seen as the total unanalyzed effect that the sign is calculated to produce. And I claim that translation equivalence should be understood as equivalence of this type of interpretant with the originally intended recipient (usually not the translator) and the recipient of the translation.

Then there is the "final interpretant," which is "the one interpretative result to which every interpreter is destined to come if the sign is sufficiently considered." This may correspond to a hermeneutic interpretation, to a commentary, etc., but, I suggest, not to an optimal translation (at most, to an overtranslation). Let us illustrate this with a German translation from the Russian psychologist and psycholinguist Leont'iev:

(1) Dejatel'nost' kak celostnyj akt imeet...edinuju motivaciju. Ona organizuetsja vsegda takim obrazom, ctoby... "Die Tätigkeit als ganzheitlicher Akt hat...eine kohärente Motivation; der Tätigkeitsakt wird immer so organisiert, daß.."

Here, the translator has correctly understood that the author uses, in the first sentence, the Russian word for activity in a rather vague and undifferentiated way, whereas the pronoun which starts the second sentence refers to the activity of performance; and this final interpretant appears in the above_ cited first German translation. I would suggest this may be put into a commentary (or into a footnote or into parentheses), whereas the translation itself should aim at the immediate interpretant which is best guaranteed by either lexical repetition (diese Tätigkeit, "this activity," the translator's second version) or by using an anaphoric pronoun. And as we will see, the above-cited first translation represents an unjustified marked translation, and thus the translator was right in changing it.

A final warrant on the use of markedness; by this I do not mean overall markedness, but a marked option on a specific universal, semiotically based parameter. In this contribution I must limit myself to universal markedness (neither typological nor languagespecific preferences, see Dressler 1983) and to the most important text-semiotic parameters.

\section{ICONICITY}

Within the Peircean sign triad of icons, indices, and (conventional) symbols, icons are the most natural signs or, more precisely, all linguistic signs are, at least minimally, conventional/symbolic (Saussure's "arbitraire du signe"), but they may simultaneously contain iconic and/or indexical aspects, and the more iconicity they contain, the more natural/more preferred/less marked they are. This establishes the universal parameter of iconicity (with its subparameters) where iconicity means similarity between signans and signatum in the mind of the interpeter.

On the text level, the best known aspect of iconicity is the universal preference for the ordo naturalis (Enkvist 1981; Levelt 1983). The ordo naturalis represents, so to speak, a diagram between cognitive order (i.e., the cognitively perceived order of events) and sentence order. For example, in the Roman cookbook of Apicius there is nearly only ordo naturalis, and translations retain this ordo naturalis, such as in

(2a) recipe n.104: Apium coques ex aqua nitrata, exprimes et concides minutatim. In mortario teres piper, ligusticum, origanum, cepam, vinum, liquamen et oleum. Coques in pultario, et sic apium commisces.

Faites cuire du céleri à l'eau avec du carbonate de soude, égouttez-le et hachez-le finement. Pilez dans un mortier du poivre, de la livèche, de l'origan, de l'oignon, du vin, du garum et de l'huile. Faites cuire dans un plat à bouille et mélangez-y alors le céleri. 
Koche eine Sellerieknolle in Wasser mit Natronzusatz, drïke sie aus und schneide sie in kleine Stückchen. Dann verarbeite im Mörser Pfeffer, (...) und Öl. In der Kasserolle aufkochen lassen und die gehackte Sellerie darunterstreichen.

Here the sequential order of phrases in the recipe follows closely the chronological order of steps in the actions the cook has to take. Thus the addition of dann, "then", in the German translation is unnecessary, because the German reader also expects the ordo naturalis to prevail.

The ordo naturalis holds not only for finite verbs within main clauses but also for embedded participles as in (2b) and embedded secondary clauses as in (2c):

(2b) n.268: Assam a furno simplicem salis plurimo conspersam cum melle inferes.

La viande est rôtie au four, sans sauce, saupoudrée abondamment de sel et servie avec du miel.

Im Rohr gebratenes Fleisch bestreue reichlich mit Salz und serviere es mit Honig.

(2c) n.290: Pernam, ubi eam...elixaveris, detracta cute tessellatim incidis.... Et cum farina cocta fuerit, eximas furno et ut est inferes.

Après avoir fait cuire le jambon à l'eau (...) détachez la couenne et faites des incisions en carrés (...). Quand la pâte sera cuite, enlevez du four tel quel et servez.

Wenn du die Keule (...) gekocht hast, dann entferne (...). Ist der Mehlüberzug braun gebacken, dann nimm die Keule aus dem Ofen und serviere sie, so wie sie ist.

In all these cases the unmarked ordo naturalis of the Latin original is translated by the same unmarked iconic device in the French and German translations. These are therefore unmarked translations on the parameter of iconicity. as in

There are very few examples where the ordo naturalis appears to be violated, such

(2d) n.83: Cucumeres rasos elixabis cum cerebellis elixis.

Concombres pelés: Faites-les bouillir avec des cervelles cuites à l'eau.

Schmore die geschälten Gurken mit gebrühten Schweinehirnchen.

where the cooking of the pork brains is of such minor importance that it is embedded into an attributive participle without consideration of chronological order.

In our last example a non-chronological appendix is added as an afterthought right at the end of a recipe for the preparation of rose wine:

(2e) n.4: ...Sane custodito ut rosam...optimam mittas.

Prenez bien soin de mettre des roses de premier choix.

Man beachte, daß man nur die besten (...) Rosenblätter nehme.

In the rare cases of ordo artificialis (as in $2 \mathrm{~d}$,e) the violation of the diagrammatic preference for the ordo naturalis is justified. This marked order is therefore translated in the same way. Hence these are unmarked translations as well.

Another instance of diagrammaticity can be observed in the unmarked word order of functional sentence perspective (Sgall 1987). If on the cognitive level that which is known is the starting point for what is new, and if on the expression level the theme (given/known) precedes the rheme (new/unknown), then we have diagrammaticity again. Let us examine a German translation of Pasolini (1977/1982). In a translation unit where Pasolini speaks about the koine italiana, he continues in the second sentence of 
(3a) Questo implica un fatto che del resto è ben noto: "in Italia" non esiste una vera e propria lingua italiana nazionale.

es gibt in Italien keine wirkliche Nationalsprache.

with a thematic element, whereas in the German translation a verb precedes it, as if something entirely new were presented such as in the very first sentence of a paragraph or chapter. The same occurs with the hypertheme of two paragraphs in:

(3b) La nuova lingua tecnologica della borghesia, di per sé, non m'interessa, personalmente la detesto, e il mio assunto di scrittore è quello di oppormi ad essa: ma non ignorandola.

An sich interessiert mich die neue technologische Sprache der Bourgeoisie nicht, persönlich verachte ich sie (...).

In both instances the diagrammatically unmarked order of the original is not preserved in the translation. Thus this is a marked translation, and since there does not seem to be any justification for this deviation, it is an inadequacy.

So far we have dealt with paradigmatic diagrammaticity, i.e., with diagrammatic relationships between meaning and form. Now we are going to pass to a syntagmatic type of diagrammaticity, i.e., parallelism. Identity of position of the same or similar elements (as is well known in simultaneous interpretation) facilitates both production and perception (see Lang 1987) due to its iconicity. Parallelism is thus a preferred option in all types of texts (see Weinrich 1972), including poetry. Let us examine Paul Éluard's poem "L'Amoureuse" as translated by Samuel Beckett, where we have the sequence:

4a) Elle est debout sur mes paupières...

Elle a la forme de mes mains,

Elle a la couleur de mes yeux,

Elle s'engloutit dans mon ombre

Comme une pierre sur le ciel.

4b) She is standing on my lids...

She has the colour of my eye

She has the body of my hand

In my shade she is engulfed

As a stone against the sky.

Not only does Beckett invert the order of sentences (which is rather rare in itself), but he also violates parallelism in the penultimate line, without any other apparent reason than the great liberties that Beckett takes in translating. This contradicts Jakobson's claim about the inherent poetic quality of parallelism (see also the critiques in Werth 1976).

Somewhat different is our next example taken from Arthur Rimbaud's "Le Bateau ivre" as translated by Beckett:

(4b) Plus léger qu'un bouchon j'ai dansé sur les flots

Qu'on appelle rouleurs éternels de victimes,

Dix nuits, sans regretter l'oil niais des falots.

Plus douce qu'aux enfants la chair des pommes sures,

Nine nights like a cork on the billows, I danced

On the breakers, sacrificial, for ever and ever,

And the crass eye of the lanterns was expunged.

More firmly bland than to children apples' firm pulp... 
Here, the first French comparative is not translated by a parallel, sentence-initial English comparative, because the morphologically unmarked translation would be the synthetic comparative "lighter" which could not form an easily recognizable parallelism with the second, analytic comparative. There is thus a grammatical justification for this marked translation. However, this is not the case with the following stanza-initial clauses of the same poem and translation:
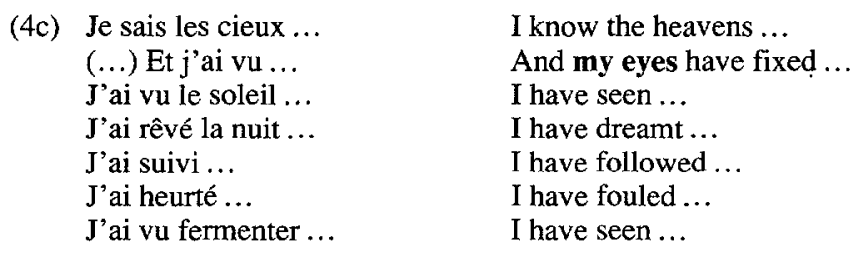

where the second line apparently presents an overtranslation of the Aktionsart of the French passé simple, a marked translation as well.

\section{INDEXICALITY}

This parameter is based on the character of the indexical signans defined by Peirce as that "which like a pronoun demonstrative or relative, forces the attention to the particular object intended (= indexical signatum) without describing it". First of all, a maintenance of indexicality in translation implies that an equivalent indexical signans refers to an equivalent indexical signatum. This is not the case in the following translation unit from Pasolini (1977/1982):

(5) Tale individuo quale sede spirituale o coabitazione della dualità, è il borghese o piccolo borghese italiano, con la sua esperienza storica e culturale, che è inutile qui definire: credo basti semplicemente alludervi come a una comune conoscenza.

Dieses Individuum als geistiger Sitz oder gemeinsame Wohung der Zweifaltigkeit ist der italienische Bourgeois oder Kleinbürger mit seiner geschichtlichen und kulturellen Erfahrung, den zu definieren sich hier erübrigt; es genügt, glaube ich, auf ihn anzuspielen wie auf etwas allgemein Bekanntes

where the Italian (here: anaphoric) deictic clitic -vi refers back to the whole experience of the Italian bourgeois, whereas the German pronoun ihn refers only to the bourgeois himself.

On the parameter of indexicality, anaphoric indexicality is universally preferred over cataphoric indexicality, because the former establishes a more reliable sign relationship; anaphora refers backwards to what is already known, whereas cataphora refers to a (potentially) still-uncertain future. Thus anaphoricity, as in examples (1) and (5), is the unmarked option, and cataphoricity the marked option. One representant of this marked option is the marked stylistic strategy of jumping in, which can be illustrated by the first page of a novel by Thomas Mann (see Harweg 1968):

(6a) Seine Geburt war unordentlich ... er ... Moses.

"His birth was unorderly ... he ... Moses."

where only after a page-long series of cataphoric pronouns we finally learn who is the indexical signatum, namely Moses. This marked strategy is of course maintained in the (therefore unmarked) translation.

A more delicate illustration of jumping in can be found with Italian interfixes (Dressler and Merlini 1989). Diminutives with (morphopragmatic) interfixes prefer 
anaphoric position with regard to diminutives (or, a fortiori, simplicia) without interfixes, such as in the dialogue between a lady (A) and her gardener (B):

(6b) A: Già, e le mie piant-ine, mentre sono via?

"Well, and my little plants, while I'm away?"

B: Innaffieremo anche le sue amate piant-ic-ine.

"We'll water your beloved little plants as well".

As both spontaneous speech and tests run by L. Merlini Barbaresi have shown, native speakers of Italian nearly always prefer this order simplex/diminutive — interfixed diminutive.

However, in the Italian newspaper Corriere della Sera I found a report on the derailment of the Brenner express train near Bologna which starts with:

(6c) Così un vecchio ponticello ha "tradito" il treno "So hat ein liebes altes Brücklein den Zug verraten"

Un "ponticello" costruito dai nostri nonni non ce l'ha fatto più. Erano passato da poco le 23,30 quando il treno è arrivato a scavalcare in piena velocità quel piccolo ponte di appena tre metri...

"Ein von unseren Großvätern erbautes liebes altes Brücklein hat es nicht mehr geschafft. Es war kaum 23 h 30 vorbei, als der Zug in voller Geschwindigkeit jene kleine Brücke von kaum drei Metern zu überfahren begann".

Here already the title starts with two emotive elements which are meant to, cataphorically, arouse tension and interest, i.e. the interfixed diminutive of ponte, "bridge" and the metaphoric verb tradire, "to betray". The first sentence of the text (again with the interfixed diminutive) also continues this emotive register, whereas the second sentence falls back into the expected sober news report register. In the proposed German translation, I have tried to maintain this marked strategy. But inspite of representing an unmarked translation as to the parameter of indexicality, this translation fails the requested German newspaper register. An universal preference is thus overridden by text-stylistic demands.

As Peirce has clearly expressed in his above-cited characterization of indices, pure indices may not be descriptive. And this holds, true both for pronominal and zero anaphora. Anaphoric lexical recurrence (repetition), however, contains the same amount of descriptivity as the repeated antecedent, albeit without adding any new descriptive element. But if these anaphoric elements are substituted with a new coreferent, but only a partially synonymous word or word group, then this represents a descriptive paraphrasis which adds symbolicity and, possibly, pragmatic value which reveals the author's perspective. Such pragmatic reloading is evident in the following translation unit from "Robinson Crusoe", where Defoe speaks about Friday and other victims of cannibals:

(7) I perceived ... two miserable wretches dragged from the boats ... I perceived one of them immediately fell $(\ldots)$ while the other victim was left standing (...) In that very moment this poor wretch (...) and he started away from them (...) and this saw plainly, he must necessarily swim over, or the poor wretch would be taken there. But when the savage escaping came thither, he made nothing of it. (I omitted 8 instances of he.)

"Da bemerkte ich $(\ldots)$, wie man zwei Unglückliche aus den Booten $(\ldots)$ herbeischleppte (...) Den einen davon sah ich alsbald (...) niederstürzen... während das andere Schlachtopfer wartete (...) In diesem Augenblick zuckte er zusammen und rannte (...) Es war klar, da $\beta$ der arme Kerl diese durchschwimmen mußte, wenn er nicht in die Hände der Verfolger fallen sollte. Wirklich warf sich der Flïchtling (...)" 
As we can see, the German translation also contains a similar variation among these different anaphoric elements. However, the respective choices are made in different places, i.e., mere indexicality vs. symbolic reloading does not occur at the same places in the original as in the German translation. The German translator has obviously taken Defoe's varying choices as a matter of pure and random stylistic variation in order to avoid tiresome repetitions and reacted with truly random variation. Thus this translation has changed the information flow and shifts in author perspective: it is a marked translation and, because of a lack of sufficient justification, an inadequate translation.

\section{TRANSPARENCY}

According to Koj (1979) Transparency to meaning ... appears precisely when we completely cease to perceive the material shape of a sign ... and are conscious only of its semantic sign, i.e., when cognitive or pragmatic or semantic meanings are directly reflected on the surface of the text without further necessity for inferencing or reconstructive processing. Of course, full transparency can be obtained only in an idealized state of affairs where economy of processing is not necessary; normally we find varying degrees of opacity.

For example, in trains we can read the inscriptions:

(8) Do not lean out

Ne pas pencher en dehors

Nicht hinauslehnen

È pericoloso sporgersi

In none of the four versions is the window mentioned. However, this noun can be easily inferred, because these inscriptions are always written beneath the window so that there is little real opacity in the material context of the situation. However, the Italian version gives a justification - often Italian public, postfascist inscriptions appeal to the intelligence of their intended readers - which at first glance makes the prohibition to lean out somewhat opaque. One may even think of an adventurous person who, when reading this inscription, may feel encouraged to take a risk. However, in the social context of the situation or within the frame of public transport in general and of trains in particular, risks are understood to be avoided. This shows us that the degree of transparency (or opacity) can only be calculated within the context of situation (situationality of Beaugrande and Dressler 1981), or within the cotext of which the respective text chunk forms a part.

Since we are more interested in cotext than in context, let us return to (iconic and indexical) repetition and its role on the parameter of transparency. Let us start with Anthony's famous repeated sentences in his funeral speech in Shakespeare's Julius Caesar:

(9a) For Brutus is an honourable man

And - " - " "

For sure he - " -

The illocutionary force of Anthony's sentence may be opaque or ambiguous to his readers the first time. But with each repetition the new context helps to disambiguate the intended meaning, i.e., repetition renders the meaning more transparent. Obviously, this is only possible because the hearer is both able to grasp the indexical character of repetition and is led to assume the diagrammaticity of this indexical relationship, i.e., to assume that these repeated sentences always have the same meaning. Obviously, translations such as Schlegel's German translation: 
(9b) Denn Brutus ist ein ehrenwerter Mann

Und - " - " -

Und ist gewiss - " -

retain this repetitive device - but maybe also for the perlocutionary force of this type of poetic repetition. But repetition is also worth maintaining in prose, as exemplified in another translation unit from Pasolini:

(10) Nei tempi "classici" (...) ora la produzione immensamente aumentata di idee (...) e la rapidità della circolazione le bruciano rapidamente: e con esse bruciano i loro codici.

"In den "klassischen" Zeiten (...) Die immense gesteigerte Produktion von Ideen (...) und die Geschwindigkeit ihrer Zirkulation zehren sie heute rasch auf: und mit ihnen verdorren ihre Kodes".

In addition to weakening the position effect of the parallelism between "in the classical times (...) today", the translator translates the recurrent instances of bruciano, "they burn down", in two different ways, thus destroying repetition. As a result the metaphoric (i.e., weakly iconic) relation between the two types of decay in the adjacent sentences is seriously weakened - an unjustifiedly marked and thus inadequate translation.

In any event, the amount of transparency/opacity should remain the same in an unmarked translation, as in Eichinger's (1987) plea for retaining ambiguity (or rather polyvalence, Beaugrande 1978) in the translation of legal texts.

\section{FIGURE AND GROUND}

This parameter of contrasting a more important, more precise, more dynamic figure (or foreground) with a less important, more pallid, more static ground (or foreground) has been taken over from Gestalt psychology into semiotics (Ertel 1981; Holenstein 1976; Scherer 1984: 156ff). This parameter seems to be adequate for capturing hierarchies within the rhythmic structuring of sequential linearization of texts. This rhythmic structuring follows - again iconically - from underlying cognitive, pragmatic and semantic hierarchies.

Languages have several means for enhancing the contrast between foreground and background (see Grimes' 1982 concept of staging) by operations of foregrounding vs. backgrounding, such as: 1) verbal aspect, i.e., the difference between perfective and imperfective aspect (and its equivalents); 2) embedding into secondary clauses, participles or preposition/noun phrases; 3 ) (compensatory) particles. Let us reanalyze a translation unit from Ernest Hemingway's The Old Man and the Sea (Wandruszka 1957):

(11) They walked down the road to the old man's shack and all along the road, in the dark, barefoot men were moving, carrying the masts of their boats.

"Ils descendirent (...) des gens se mouvaient, (...), les mâts de leurs bateaux sur leurs épaules".

"Scesero (...) si muovevano uomini scalci, che portavano" (...)

"Marcharon (...) se veían hombres descalzos portando..."

"Sie gingen die Landstraße hinunter bis zu der Hütte des alten Mannes, und die ganze Straße entlang im Dunkeln bewegten sich barfüssige Männer, die die Masten ihrer Boote trugen".

According to the criterion of verbal aspect, the English simple form walked refers to the foreground, the progressive/expanded form were moving to the background. By 
embedding, the participle carrying is still further backgrounded. The Spanish translation comes closest with the equivalent triad pretérito perfecto simple, imperfecto, participio. The French translation comes close with passé simple, imparfait, and a nominalized phrase. The Italian translation as well, with passato remoto, imperfetto and an imperfetto embedded into a secondary (i.e., relative) clause. All these are unmarked translations. Embedding into a relative clause is also chosen in the German translation. However, since German has no grammatical equivalent to verbal aspect, the translator has flattened the difference between figure and ground by translating both the English simple and progressive form by a German preterit. This is a marked translation, and an inadequate one, I suggest, because there would have been compensatory means of backgrounding available, such as embedding the second clause into a secondary while-clause, e.g.:

(11’) ..während sich...barfüssige Männer bewegten..

A similar problem can be found in Ungaretti's poem In memoria as translated into German by the Austrian poet Ingeborg Bachmann:

(12) Si chiamava

Moammed Sceab

Discendente

di emiri di nomadi suicida

perché non aveva piú

Patria

Amò la Francia

e mutò nome

Fu Marcel

ma non era Francese
Er hiess

Mohammed Sheab

Abkömmling

von Emiren von Nomaden

Er beging Selbstmord

weil er kein Land

mehr hatte

Er liebte Frankreich

und änderte seinen Namen

Wurde Marcel

war aber nicht Franzose...

Here, as well, fore/backgrounding by means of the Italian passato remoto and imperfetto is rendered in German by preterits only, with one exception: the ingressive Aktionsart of the perfective aspect of It. $F u$ is rendered by the lexically ingressive preterit wurde, "became". This looks like an overtranslation (in contrast to the undertranslations of verbal aspect differences in the other lines), but there is a second reason: if Bachmann had chosen the literal translation war, "was", then this tensed form would have been identical to the translation of the imperfective It, era in the immediately following line. As a result of this repetition, the reader would have been falsely led to think that this pair of identical verb forms should have exactly the same meaning.

My final example - from Vergil's Aeneis, where Aeneas and his companions are within the burning city of Troy - is meant to illustrate (frequent!) parameter conflicts:

(12) Moriamur et in media arma ruamur

"Come, let us die, we'll make a rush into the thick of it"

"Mourons et jetons-nous au milieu des armes"

"Moriamo, e gettiamoci tra le armi"

Thassilo von Scheffer: "So stürzen wir denn zum Kampf und zum Tode"

This exhortation clearly violates the diagrammatic parameter of the ordo naturalis in its basically chronological interpretation and is thus a classical example of a hysteron proteron. However, the decision to die is foregrounded by getting sequential priority. In other words, there is a conflict between the parameters of diagrammaticity and of figure and ground. But note that this conflict functions only for identifying a text strategy as marked or unmarked, whereas it does not for translation; if the translator recodes the 
conflict in an equivalent manner from the source language into the target language, then he/she achieves an unmarked translation. The rather free German (poetic) translation represents a marked translation; the only justification for having Tode, "(to) death", after Kampf, "fight", is the tendency in binomials to have bisyllables after monosyllables and the (stressed) vowel /o:/ after the (equally stressed) vowel /a/. Translators may judge whether this is a sufficient justification!

\section{CONCLUSION}

In this brief contribution I have tried to show that seemingly unimportant properties of a text such as word order, repetition, use of pronouns, etc. have a meaning in texts, that they help to shape the flow of discourse, and that they are thus also relevant for translation. By inserting these phenomena into a semiotically based preference model, I have distinguished parametrized marked vs. unmarked text strategies. This allows to characterize deviations from these strategies in translation as marked translations. Such deviations must be justified by grammatical or stylistic patterns of the target language (which differ from those of the source language) or by reference to the specific purposes of the translator. If such justifications of marked translations are insufficient, then these translations should be qualified as inadequate. They cannot be considered as attempting to render Peirce's interpretant of the source text adequately into the target text.

\section{BIBLIOGRAPHY}

DE BEAUGRANDE, R. (1978): "Factors in a Theory of Poetic Translation", Assen, van Gorcum.

DE BEAUGRANDE, R. (1984): "Text Production", Norwood, Ablex.

DE BEAUGRANDE, R. and W. U. DRESSLER (1981): "Einführung in die Textlinguistik", Tübingen, Niemeyer.

BUCHLER, J. (1955), ed.: "Philosophical Writings of C. S. Peirce”, New York, Dover.

DRESSLER, W. U. (1983): "Notes on textual typology", in S. Rot (ed.), Languages in Function, Budapest, Akadémiai Kiádó, pp. 77-83.

DRESSLER, W. U. (1985): "Morphonology", Ann Arbor, Karoma Press.

DRESSLER, W. U. (1987): "Die Bedeutung der Textlinguistik für Übersetzung und Umkodierung", in A Destro (ed.), Tradurre: teorie ed esperienze, Bolzano/Bozen, Educazione Bilingue/Zweisprachige Bildung, 14, pp. 21-34.

DRESSLER, W. U. (1989): "Semiotische Parameter einer textlinguistischen Natürlichkeitstheorie", Vienna, Verlag der Österreichischen Akademie der Wissenschaften.

DRESSLER, W. U. and L.MERLINI BARBARESI (1987): "Elements of Morphopragmatics", Duisburg, LAUD A 194.

DRESSLER, W. U. and L. MERLINI BARBARESI (1989): "Interfissi e non-interfissi antesuffissali nell'italiano, spagnolo e inglese", in Atti 2O. congresso SLI, Rome, Bulzoni, pp. 243-252.

ECO, U. (1984): "Semiotics and the Philosophy of Language", Bloomington, Indiana University Press.

EICHINGER, L. (1987): "Be Ambiguous, wider ein naives kommunikatives Modell für die Übersetzung von Vertrags- und Gesetzestexten", in A.Destro (ed.), Tradurre: teorie ed esperienze, Bolzano, Educazione Bilingue, 14, pp. 93-105.

ENKVIST, N. (1981): "Experiential Iconicism in Text Strategy", Text, 1, pp. 71-111.

ERTEL, S. (1981): "Wahmehmung und Gesellschaft. Prägnanztendenzen in Wahrnehmung und Gesellschaft. Prägnanztendenzen in Wahrnehmung und Bewusstsein", Zeitschrift für Semiotik, 3, pp. 107-141.

GRIMES, J. (1982): "Reference Spaces in Text", S. Allén (ed.), Text Processing, Stockholm, Almqvist \& Wiksell, pp. $381-414$.

HARWEG, R. (1968): "Pronomina und Textkonstitution", Munich, Fink.

HOLENSTEIN, E. (1976): "Linguistik, Semiotik, Hermeneutik: Plädoyers für eine strukturale Phänomenologie", Frankfurt, Suhrkamp.

HOOKWAY, C. (1985): "Peirce", London, Routledge.

KOJ, L. (1979): "The principle of transparency and semantic antinomies", in J. Pelc (ed.), Semiotics in Poland, Dordrecht, Reidel, pp. 376-406.

KÖNIGS, F. (1986): "Recherches en traductologie en République fédérale d'Allemagne", Meta, 31, pp. 119-136.

LANG, E. (1987): "Parallelismus als universelles Prinzip sekundärer Strukturbildung", Linguistische Studien, A 161, pp. 1-54. 
LEVELT, W. (1983): "The Speaker's Organization of Discourse", PICL, 13, pp. 278-290.

MERLINI BARBARESI, L. (1988): Markedness in English Discourse, Parma, Zara.

PASOLINI, P. P. (1977) : Empirismo eretico. Saggi, Milan, Garzanti; translated as Ketzererfahrungen by

R. Klein, Frankfurt, Ullstein, 1982.

PEIRCE, Ch. S. (1965): Collected Papers, Cambridge, Harvard University Press.

PETÖFI, J. S. (1986): "Report: European Research in Semiotic Textology", Folia Linguistica, 20, pp. 545-571.

REISS, K. and H. VERMEER (1984): Grundlegung einer allgemeinen Translationstheorie, Tübingen, Niemeyer.

SGALL, P..(1987): "The Position of Czech Linguistics in Theme-Focus Research", in R. Steele and T. Treadgold (eds.), Language Topics (Fs. Halliday), Amsterdam, Benjamins, pp. 47-55.

SCHERER, B. (1984): "Prolegomena zu einer einheitlichen Zeichentheorie", Tübingen, Stauffenburg.

WANDRUSZKA, M. (1957): "Strukturen moderner Prosa", Der Deutschunterricht, 7;3, pp. 89-104.

WEINRICH, H. (1972): "Thesen zur Textsortenlinguistik", in E. Gülich and W. Raible (eds.), Textsorten, Frankfurt, Athenäum, pp. 161-169.

WERTH, P. (1976): “Roman Jakobson's Verbal Analysis of Poetry", Journal of Linguistics, 12, pp. 21-75. 